\title{
SAME-SEX MARRIAGE: EXPLORING THE IMPLICATIONS OF OBERGEFELL $V$. HODGES ON THE PHILIPPINES' MUSLIM LAW OF MARRIAGE AND THE 1987 CONSTITUTION
}

\author{
Norhabib Bin Suod Sumndad Barodi*
}

\begin{abstract}
In view of the recent development brought about by the decision of the U.S. Supreme Court in Obergefell v. Hodges, jurisdictions that retain the traditional definition of marriage have sufficient reasons to revisit the concept of marriage under their own laws. This article is an academic effort to explore whether the traditional or historic definition of marriage adopted in the Philippines, as articulated in its Constitution and other pertinent laws like the Code of Muslim Personal Laws of the Philippines can withstand the new norm that Obergefell established in the legal system or constitutionalism of the United States. It attempts to project how the issue of same-sex marriage would be treated and decided in the Philippine context had it been an issue for which the Philippine legal system or constitutionalism is made to respond. This article emphasizes the incompatibility of the Obergefell decision with the Islamic definition of marriage and finds that the same decision is not entirely square with how the issue of same-sex marriage will be dealt with in Philippine constitutionalism.
\end{abstract}

Keywords: same-sex marriage, separation of powers, political question doctrine, equal protection clause, due process clause

Assistant Professor, Mindanao State University College of Law Main Campus, Islamic City of Marawi, Philippines; Member, Integrated Bar of the Philippines; Member, Integrated Shari'ah Bar of the Philippines (ISBP); Member, Board of Directors, ISBP. The author can be contacted at nbs.barodi@gmail.com. 


\title{
PERKAHWINAN SEJENIS: MENEROKA IMPLIKASI OBERGEFELL $V$. HODGES TERHADAP UNDANG-UNDANG PERKAHWINAN ISLAM FILIPINA DAN PERLEMBAGAAN 1987
}

\begin{abstract}
ABSTRAK
Bidang kuasa yang menyimpan takrifan tradisional perkahwinan mempunyai sebab yang mencukupi untuk menilai semula konsep perkahwinan di bawah undang-undang sendiri memandang perkembangan baru yang dibawa oleh keputusan Mahkamah Agung Amerika Syarikat dalam kes Obergefell v. Hodges. Perkembangan ini menggerakkan penulisan makalah ini. Ianya merupakan satu usaha akademik untuk meneroka samada takrifan tradisional atau berdasarkan sejarah yang diterima pakai di Filipina, sebagaimana diartikulasikan dalam perlembagaannya dan undang-undang lain yang berkaitan seperti Kod Undang-undang Peribadi Islam Filipina, dapat bertahan normal baru yang diwujudkan oleh Obergefell dalam sistem perundangan atau perlembagaan Amerika Syarikat. Tanpa dapat dielak, ini memprojek bagaimana isu perkahwinan sejenis akan dikendalikan dan diputuskan dalam konteks Filipina sekiranya ia menjadi satu isu yang harus diberi maklumbalas oleh sistem perundangan Filipina atau perlembagaannya. Makalah ini menekankan ketidakcocokan keputusan Obergefell dengan takrifan perkahwinan dalam Islam dan mendapati bahawa keputusan itu tidak sepenuhnya sama dengan cara isu perkahwinan sejenisdikendalikan di bawah Perlembagaan Filipina.
\end{abstract}

Kata Kunci: takrifan perkahwinan, pengasingan kuasa, doktrin persoalan politik, klausa perlindungan yang sama, klausa proses sewajarnya

\section{INTRODUCTION}

There are legal realities that are normal in a democracy wherein defensible societal disapprobation of certain unorthodox social phenomena in the past is seen today as an injustice in this era of 
tremendous secularization. This article speaks of one of those legal realities in relation to the social phenomenon of same-sex unions. The dominance of the traditional or historic definition of marriage as a social institution that is limited to opposite-sex couples is challenged by the conclusion of the United States Supreme Court in the case of Obergefell v. Hodges. ${ }^{1}$ This controversial decision ended decades of political debate in the United States as to whether same-sex unions should be given the same degree of recognition, and consequent benefits, that the state affords to opposite-sex marriages. However, the traditional or historic definition of marriage is not a concept that permits no derogation at least insofar as secular lawmaking is concerned. It is well within the grasp of legislation, which does not preclude an expansion of the meaning of marriage to include the rapidly emerging phenomenon of unions of members of the same sex. Needless to state, legislation, which is usually influenced by clamor, has the potency to alter the traditional or historic definition of marriage. The people through their representatives in the lawmaking-body can redefine marriage subject to the parameters of the constitution.

However, the U.S. Supreme Court seemed to have redefined marriage, on its own initiative, by declaring that the non-recognition by states of same-sex marriages is violative of the Due Process Clause and the Equal Protection Clause of the U.S. Constitution. Though the Obergefell decision is of U.S. origin, this fact cannot impede a scrutiny of the same under the 1987 Constitution of the Philippines and the Muslim Law on Marriage in the Philippines for three reasons. First, the U.S. Supreme Court utilized the Due Process Clause and the Equal Protection Clause of the U.S. Constitution in requiring states to license the marriage of same-sex couples. In Philippine constitutionalism, the Due Process and Equal Protection Clauses are central to the Bill of Rights of the 1987 Constitution of the Philippines. Second, the U.S. Supreme Court seems to have acted as a legislature by expanding the meaning of marriage to include same-sex unions. In the Philippine constitutional legal framework, marriage is well-defined and the authority to modify its definition pertains not to the Supreme Court of the

Obergefell, et.al. v. Hodges, Director, Ohio Department of Health, et.al., 576 U.S. (2015). The Author used the copy of the decision that was released immediately after the U.S. Supreme Court arrived at its Opinion with a vote of 5-4, in favor of the Petitioners. 
Philippines in view of the doctrine of separation of powers by reason of which political issues are supposed to be decided by the political branches of the government. And third, the new normal introduced by the Obergefell decision in the definition of marriage is inconsistent with the Islamic definition of marriage which limits the same to opposite-sex marriages.

Certainly, the Code of Muslim Personal Laws of the Philippines adopts the Islamic concept of marriage whose meaning is limited to union between a man and a woman. However, said Code is a national law that is subject to the power of the secular lawmaking body of the Philippines to repeal laws. Therefore, the Obergefell legal phenomenon has the potential to affect the concept of marriage as understood in the context of the Code of Muslim Personal Laws of the Philippines, which operates within a secular legal system that also looks upon the American constitutional legal framework.

This convinced the present writer to revisit the concept of Marriage, Due Process Clause and Equal Protection Clause, and the Doctrine of Separation of Powers in relation to the Political Question Doctrine from the perspective of Philippine law on the matter particularly the Code of Muslim Personal Laws of the Philippines, ${ }^{2}$ the Family Code of the Philippines, ${ }^{3}$ and the 1987 Constitution of the Philippines respectively.

\section{DEFINITION OF MARRIAGE UNDER PERTINENT LAWS OF THE PHILIPPINES}

Just like in most jurisdictions all over the world especially in Muslim countries, ${ }^{4}$ the definition of marriage under Philippine laws adheres to the traditional or historic concept of marriage as a union between a man

2 Presidential Decree No. 1083, otherwise known as the 'Code of Muslim Personal Laws of the Philippines,' or Muslim Code for brevity. This is a codification of purely personal laws governing the Muslims in the Philippines. The date of effectivity of the Muslim Code was February 4, 1977.

3 Executive Order No. 209, promulgated by the late President of the Republic of the Philippines Corazon C. Aquino.

4 See "Status of same-sex marriage," http://en.wikipedia.org, last accessed August 27, 2017, 4:06 PM. 
and a woman. This is evident in Article 1 of the Family Code of the Philippines, which defines marriage as follows:

Marriage is a special contract of permanent union between a man and a woman entered into in accordance with law for the establishment of conjugal and family life. It is the foundation of the family and inviolable social institution whose nature, consequences, and incidents are governed by law and not subject to stipulation, except that marriage settlements may fix the property relations during the marriage within the limits provided by this Code.

While the Family Code of the Philippines projects the traditional or historic definition of marriage, the Code of Muslim Personal Laws of the Philippines lacks the 'union between a man and a woman' element in the language of its own definition of marriage. Article 14 thereof defines marriage as follows:

Marriage is not only a civil contract but a social institution. Its nature, consequences and incidents are governed by this Code and the Shari'a and not subject to stipulation, except that the marriage settlements may to a certain extent fix the property relations of the spouses.

However, this does not mean that the definition of marriage under the Muslim Code includes in its scope the union between same-sex couples. Far from implying that it so allows, the Muslim Code is explicit in not recognizing marriages between same-sex couples. Article 4, par. 1 of the Muslim Code provides, "In the construction and interpretation of this Code and other Muslim laws, the court shall take into consideration the primary sources of Muslim law." In other words, in the interpretation of marriage as provided for under the Muslim Code, the primary sources of Muslim law shall be considered. Hence, the marriage contemplated under the Muslim Code should be in accordance with the Holy Qur' an and the Sunnah of Prophet Muhammad (s.a.w.), which are the primary sources of Muslim law. In other words, for marriage to be recognized by the Shari'ah, it has to comply with the requisites established by Shari'ah for its validity. In this connection, absolute is the truth that both the Holy Qur'an and Sunnah contemplate marriage as a union of a man and a woman. The Arabic word for marriage is "nikah", which means uniting 
together. ${ }^{5}$ Technically, nikah or marriage is defined as a contract for the legalization of intercourse and the procreation of children. ${ }^{6}$ A legal contract, in consequence whereof, the married couple acquires the right of enjoyment of all benign association between themselves allowed under the Shari'a. ${ }^{7}$ As explained by Hussin and Muhammad:

Marriage in Islam, is at once 'ibādah and mu'ämalah. Marriage is 'ibādah because it is an act of the sunnah of the Prophet so that we can attain Allah's pleasure in efforts to continue the human race and nurture children borne out of marriage to become the servants of Allah. In its mu'amalah aspect, marriage is an aspect of the relationship between husband and wife in terms of their duties and rights in translating those rights and duties as a human institution. Islam stresses the importance for Muslims to be clearly aware of their roles in the family. As a husband or wife, each has a distinctive role to play and certain obligations to fulfill. As such, responsibilities are associated with roles to ensure balance of harmony is achieved in the family. ${ }^{8}$

These observations are articulated in the Code of Muslim Personal Laws of the Philippines. Consequently, a perusal of the Muslim Code yields a conclusion that said Code contemplates the traditional concept of marriage, which is the union between a man and woman. The Muslim Code declares in Article 1 thereof that marriage is not only a civil contract but a social institution. As explained by Alauya, "Marriage is not only a civil contract but also a social institution because its benefit is not only redounding to the interest of its contracting parties but also to individuals, family or nation." 9 Other provisions thereof clearly indicate the adherence of the Muslim Code to the traditional or historic definition of marriage like in the following instances inter alia: (1) separate

5 Bensaudi I. Arabani, Commentaries on the Code of Muslim Personal Laws of the Philippines with Jurisprudence and Special Procedures (1990), 249. Ibid.

Ibid.

Nasimah Hussin and Ramizah Wan Muhammad, "Wife Battering From an Islamic Perspective and Malaysian Legal Provisions," International Islamic University Malaysia Law Journal Vol. 16 No. 2 (2008): 204-205, accessed June 25, 2017. [Emphasis added.]

9 Saaduddin A. Alauya, The Quizzer in Muslim Personal Law (Marawi City: 1984), 4. 
capacity to contract marriage of a Muslim male and a Muslim female ${ }^{10}$ (2) mutual rights and obligations between husband and wife; ${ }^{11}$ (3) property relations between husband and wife ${ }^{12}(4)$ forms of divorce ${ }^{13}$ and (5) how legitimacy is established. ${ }^{14}$

However, the definition of marriage in both the Family Code of the Philippines and the Code of Muslim Personal Laws of the Philippines is still a statutory definition even though it adheres to the traditional or historic concept of marriage. In this connection, it is worthy to note that the 1987 Constitution of the Philippines does not contain a definition of marriage that specifically describes it as a union between a man and a woman. This omission, whether intentional or out of inadvertence, is evident in Section 2, Article XV of said Constitution, which states, "Marriage, as an inviolable social institution, is the foundation of the family and shall be protected by the State." There is no single provision of the Philippine Constitution that unequivocally alludes to marriage as a union of a man and a woman. Considering that such a definition does not clearly appear in the Constitution, then it seems that there is no clear constitutional impediment for the Congress of the Philippines to redefine marriage through a legislation that will include in the scope of marriage the unions between same-sex couples. However, there is likewise no constitutional impediment for the Congress of the Philippines to acknowledge the natural-law context of the constitutional provisions on

10 Article 16. Capacity to contract marriage. - (1) Any Muslim male at least fifteen years of age and any Muslim female of the age of puberty or upwards and not suffering from any impediment under the provisions of this Code may contract marriage. A female is presumed to have attained puberty upon reaching the age of fifteen. [Boldfacing supplied]

11 Article 34. Mutual rights and obligations. - (1) The husband and the wife are obliged to live together, observe mutual respect and fidelity, and render mutual help and support in accordance with this Code....(3) The husband and the wife shall inherit from each other in accordance with this Code. (4) The husband and the wife shall have the right to divorce in accordance with this Code. [Boldfacing supplied]

12 Article 37. How governed. - The property relations between husband and wife shall be governed in the following order...[Boldfacing supplied]

13 See Articles 45-54, Code of Muslim Personal Laws of the Philippines.

14 Article 58. Legitimacy, how established. - Legitimacy of filiation is established by evidence of valid marriage between the father and the mother at the time of the conception of the child. [Boldfacing supplied] 
family and marriage in the enactment of laws affecting the Filipino concept of family and marriage.

\section{IMPLICATIONS ON THE MUSLIM CODE OF AN EXPANDED DEFINITION OF MARRIAGE}

There is no difficulty in advancing the proposition that the Congress of the Philippines may redefine marriage to include the unions between same-sex couples. Stated differently, the Congress of the Philippines may legislate for an amended definition of marriage in the Philippines. Should this happen, then the Muslim legal scholars in the Philippines should be prepared to respond to the question of whether a modified definition of marriage that includes same-sex unions should likewise apply to Muslim marriages under the Code of Muslim Personal Laws of the Philippines. To recall, the Muslim Code is also a statute enacted through a Presidential Decree in 1977 when the President then wielded legislative power under the 1973 Constitution of the Philippines. ${ }^{15}$ It is a basic principle of Philippine constitutionalism that the national legislature cannot pass irrepealable laws.

Section 1, Article II of the 1987 Constitution of the Philippines provides in part that the Philippines is a democratic and republican state. In his treatise on political law, Philippine Supreme Court Justice (ret.) Antonio Eduardo B. Nachura writes that one of the manifestations of republicanism is that the legislature cannot pass irrepealable laws. ${ }^{16}$ Consequently, the Code of Muslim Personal Laws of the Philippines, as a national law, is subject to repeal by a subsequent national law. Hence, the Congress of the Philippines can adopt a uniform definition of marriage that includes same-sex unions through a national law that repeals all provisions of existing Philippine laws that limit the definition of marriage to its traditional or historic characterization. That national law would

15 There were four (4) constitutions that became effective in the Philippines after it gained independence from Spain. These are the Malolos Constitution, which was short lived after the Americans assumed sovereignty in the Philippines; the 1935 Constitution; the 1973 Constitution; and finally, the 1987 Constitution, which is a symbol of the EDSA People Power of 1986 that ousted and toppled the government of the late Pres. Ferdinand Marcos.

16 Antonio Eduardo B. Nachura, Outline Reviewer in Political Law (Quezon City: 2014), 73. 
include within its amendatory effect the Code of Muslim Personal Laws of the Philippines.

However, even if marriage is redefined in the Philippines, the resulting definition that includes same-sex marriages cannot and should not be applicable to Muslim marriages under the Muslim Code. In verse 3 of Surah an-Nisa, the Holy Qur' an provides in part, "Marry women of your choice..."17 The Holy Qur' an is also replete of verses that reject the concept of same-sex union, particularly sexual relations or attraction between two men. ${ }^{18}$ All Prophetic narrations that have something to do with marriage and family life allude to marriage, consistently, as a union between a man and a woman. They are too numerous to cite in this article. ${ }^{19}$ Hence, it must be noted that the definition of marriage contemplated under the Muslim Code is consistent to the perspective of the Holy Qur'an and Sunnah on marriage. For legislation not to contravene the Shari'ah, the same must not violate the Holy Qur'an or Sunnah. Therefore, any national law in the Philippines that will establish an expanded definition of marriage that includes same-sex unions is definitely contrary to the Islamic definition of marriage, which is limited to union between a man and a woman. The Islamic definition of marriage is irrepealable for any attempt to insert same-sex unions in the definition would be to abrogate the Holy Qur'an and Sunnah. Man-made legislations cannot abrogate the rules laid down by Allah (s.w.t.) as the Supreme Legislator.

At this juncture, this writer will incorporate into the discussion two important variables, to wit: (1) the Congress of the Philippines is a secular legislature, and (2) the Muslims in the Philippines constitute the minority both in the number of population and the number of representatives in the Congress of the Philippines. The Congress of the Philippines cannot be dictated to define marriage in accordance with the Holy Qur'an or the Bible for such a legislature is secular. Even if the

17 Mushaf Al-Madinah An-Nabawiyah, trans., The Holy Qur'an, English Translation of the Meanings and Commentary (Al-Madinah AlMunawarah: King Fahd Holy Qur'an Printing Complex, 1989), 206.

18 See Holy Qur'an, 11:77-83; 15:61-77; 29:28-30; 7:81-84.

19 Dr. Muhammad Muhsin Khan, trans., The Translation of the Meanings of Summarized Sahih Al-Bukhari, Arabic-English (Riyadh - Saudi Arabia: Maktaba Dar-us-Salam Publishers \& Distributors, 1994), Hadith Nos. 1828 - 1871 of The Book of Nikah, 886-906. 
Muslim representatives to the Congress of the Philippines will block a modified definition of marriage that is inconsistent with the Holy Qur'an and Sunnah, such an effort would be an exercise in futility for the number of Muslim Congressmen in the House of Representatives does not even constitute ten (10) percent of the total membership of said House. In fact as of this writing, not a single member of the Senate of the Philippines is a Muslim. However, there is no legal impediment for the Congress of the Philippines to afford a legal accommodation that retains the traditional or historic definition of marriage insofar as the Muslims in the Philippines are concerned.

In the Philippines, the non-recognition of polygamy and divorce is the prevailing rule for non-Muslim marriages. The exceptions to this rule are found in the Code of Muslim Personal Laws of the Philippines. Under the said Code, the Muslim husband is granted the right to marry subsequently under certain conditions and retain not more than four wives at a time. ${ }^{20}$ Furthermore, divorce is available to the Muslim spouses under the Muslim Code. ${ }^{21}$ While in the Philippines polygamous marriages and divorces are not allowed, nevertheless Philippine laws on the matter afforded a legal accommodation by allowing these rights to be legally available for Muslims under the Muslim Code. Similarly therefore, the Congress of the Philippines can redefine marriage to include unions of same-sex couples but at the same time specifically provide an exception thereto by making the recognition of same-sex marriage inapplicable to Muslim marriages under the Muslim Code.

\section{GIVING RECOGNITION TO SAME-SEX MARRIAGE: A POLITICAL QUESTION THAT CALLS FOR FAITHFULLNESS TO THE DOCTRINE OF SEPARATION OF POWERS}

It is the view of the present writer that the issue of whether to recognize same-sex marriage is a political question. As far as Philippine constitutional law is concerned, it is not really difficult to establish the

20 Article 27 of the Muslim Code provides, "Notwithstanding the rule of Islamic law permitting a Muslim to have more than one wife but not more than four at a time, no Muslim male can have more than one wife unless he can deal with them with equal companionship and just treatment as enjoined by Islamic law and only in exceptional cases."

21 See Articles 45 to 54, Code of Muslim Personal Laws of the Philippines. 
nexus between this divisive issue and the political question doctrine. We will see though that the political question argument was rejected in Obergefell. Black's Law Dictionary defines 'political question' as a question that a court will not consider because it involves the exercise of discretionary power by the executive or legislative branch of government, and 'political-question doctrine' as the judicial principle that a court should refuse to decide an issue involving the exercise of discretionary power by the executive or legislative branch of government. ${ }^{22}$ The political question doctrine is a judicial construct that stands for the proposition that there are or may be certain types of issues that are committed to an elected branch of government and thus should not be heard in federal court. ${ }^{23}$ The political question doctrine's philosophy is " "essentially a function of the separation of powers,", rooted in Jeffersonian notions of constitutional theory that democracy is best served by having coordinate elected branches resolve political questions rather than politically unaccountable federal judges. ${ }^{24}$

However, the case of Obergefell v. Hodges seems to have departed from this basic principle in political law. Before the promulgation of the Obergefell ruling, the status quo in the United States was that the states, whose laws adhered to the traditional or historic definition of marriage, still constituted the majority. It seems that the U.S. Supreme Court indirectly imposed an expanded definition of marriage upon state legislatures through judicial legislation in the Obergefell decision. In his dissenting opinion, Chief Justice Roberts of the U.S. Supreme Court writes as follows:

Understand well what this dissent is about: It is not about whether, in my judgment, the institution of marriage should be changed to include same-sex couples. It is instead about whether, in our democratic republic, that decision should rest with the people acting through their elected representatives, or with five lawyers who happen to hold

22 Black's Law Dictionary, Ninth Edition, p. 1277.

23 James R. May, AEP v. Connecticut and the Future of the Political Question Doctrine, 121 YALE L.J. ONLINE 127 (2011), http://yalelawjournal.org/2011/09/13/may.html.

Ibid. 
commissions authorizing them to resolve legal disputes according to law. The Constitution leaves no doubt about the answer. ${ }^{25}$

Clearly, Chief Justice Roberts was of the view that the issue in Obergefell was a political one that should have been decided by the people through their elected representatives in the democratic republic. In other words, it is for the state legislatures to decide whether same-sex unions should be included in the definition of marriage. This is coherent with the doctrine of separation of powers. Courts are not supposed to lay down policies, least of all to legislate. And Chief Justice Roberts did not fail to raise this point vigorously. At the outset of his dissent, he immediately pointed out that the Court is not a legislature. ${ }^{26}$ "Although the policy arguments for extending marriage to same-sex couples may be compelling," he continued, "the legal arguments for requiring such an extension are not." 27 In this connection, one has to be mindful of the legal reality that courts of law and justice do not decide issues based on policy arguments. Otherwise, courts would be converted, in effect, into political tribunals. Truly, it is not for the U.S. Supreme Court, or any court for that matter, to dwell on a political controversy for the prerogative to resolve the same pertains to the people through their elected representatives in their respective states. Otherwise, through judicial legislation, courts become intruders into the domain of the legislative department in violation of the doctrine of separation of powers.

However, it would be unfair and inaccurate to say that the U.S. Supreme Court is not familiar with the proper application of the political question doctrine since it first appeared in Marbury v. Madison. ${ }^{28}$ In the first place, for the U.S. Supreme Court not to treat the issues in Obergefell as political questions is not surprising. This is because the political question doctrine is not a magical formula that will automatically dissuade the court from deciding on the case the moment there is an invocation of the involvement of a political issue. As observed by James R. May, Professor of Law at Widener University,

\footnotetext{
25 See Roberts, C.J., dissenting, Obergefell, 576 US (2015) .

26 See ibid.

27 Ibid.

285 U.S. (1 Cranch) 137 (1803).
} 
The political question doctrine has been one of "limited application." It has applied rarely and idiosyncratically to "political questions" devoted to the elected branches, not simply in cases that involve political issues. Accordingly, the Supreme Court has seldom invoked the doctrine, limiting its application to an extraordinarily small array of cases including political apportionment and gerrymandering, foreign relations, impeachment, and constitutional amendments. ${ }^{29}$

In fact, Obergefell did not attempt to evade the political question arguments. The Opinion met head on both the warning of the respondents that "there has been insufficient democratic discourse before deciding an issue so basic as the definition of marriage" and the "cogent argument" of the majority opinion for the Court of Appeals that "it would be appropriate for the respondents' States to await further public discussion and political measures before licensing same-sex marriages.",30 In other words, these arguments would have us believe that the Obergefell issues are political in nature and so therefore, there may be "an initial inclination in these cases to proceed with caution - to await further legislation, litigation, and debate." ${ }^{31}$ In response, the Obergefell opinion observed that:

Yet there has been far more deliberation than this argument acknowledges. There have been referenda, legislative debates, and grassroots campaigns, as well as countless studies, papers, books, and other popular and scholarly writings. There has been extensive litigation in state and federal courts. [...] Judicial opinions addressing the issue have been informed by the contentions of parties and counsel, which, in turn, reflect the more general, societal discussion of samesex marriage and its meaning that has occurred over the past decades. As more than 100 amici make clear in their filings, many of the central institutions in American life-state and local governments, the military, large and small businesses, labor unions, religious organizations, law enforcement, civic groups, professional organizations, and universities — have devoted substantial attention to

29 James R. May, AEP v. Connecticut and the Future of the Political Question Doctrine, 121 YALE L.J. ONLINE

127 (2011), http://yalelawjournal.org/2011/09/13/may.html. [Citations omitted.]

30 Obergefell, 576 US ___ (2015).

31 Ibid. 
the question. This has led to an enhanced understanding of the issuean understanding reflected in the arguments now presented for resolution as a matter of constitutional law. ${ }^{32}$

In his 're-review' of The Case for Same-Sex Marriage: From Sexual Liberty to Civilized Commitment by William N. Eskridge, ${ }^{33}$ Richard A. Posner $^{34}$ explained, “...a decision by the Supreme Court in 1997 establishing a right to homosexual marriage in all states would have been a mistake. A change in public opinion was required to make the judicial creation of such a right acceptable. The change occurred. By 2011 a majority of Americans supported authorizing same-sex marriage." ${ }^{, 35}$ In other words, at the time that the Obergefell cases were decided by the U.S. Supreme Court in 2015, the issue of authorizing same sex marriage, as a 'question to be decided by the people in their sovereign capacity, 36 is settled already in the affirmative by the American public opinion.

Let us now proceed to another angle in the application of the political question doctrine. In his Comment published by The Yale Law Journal, Chris Michel writes that:

Modern political questions have coalesced into two primary categories. First, courts will not adjudicate claims arising from "a textually demonstrable constitutional commitment of the issue to a coordinate political department." [...] Second, courts will not adjudicate claims that present "a lack of judicially discoverable and manageable standards., 37

The Case for Same-Sex Marriage: From Sexual Liberty to Civilized Commitment by William N. Eskridge, Jr. New York: The Free Press, 1996.

34 Judge, U.S. Court of Appeals for the Seventh Circuit; Senior Lecturer, University of Chicago Law School.

35 Richard A. Posner, "Eighteen Years On: A Re-Review," The Yale Law Journal Vol. 125 No. 2 (2015): 539, accessed August 27, 2017.

36 See Tañada v. Cuenco, 100 Phil. 1101.

37 Chris Michel, "There's No Such Thing as a Political Question of Statutory Interpretation: The Implications of Zivotofsky v. Clinton," The Yale Law Journal Vol. 123 No. 1 (2013): 255-256, accessed August 27, 2017. 
For James R. May, Professor of Law at Widener University:

The Constitution does not expressly recognize a field of "political questions" - including for environmental issues - beyond the reach of the federal judiciary. Nonetheless, the Supreme Court has observed that there are certain "formulations" of matters that are textually or prudentially committed to an elected branch of government, or otherwise imprudent for judicial evaluation. A "textual" commitment occurs when, for example, the Constitution specifically delegates an issue to an elected branch, say, with the impeachment process. A "prudential" commitment occurs when, for example, there is a lack of judicially discernible standards to apply in the case. ${ }^{38}$

Pursuant to the political question doctrine, when the issue for resolution is textually demonstrable to be committed by the Constitution to a co-equal political branch of government, then courts cannot pass upon said issue without violating the doctrine of separation of powers obtaining between the judicial and the political departments of government. Of course, the U.S. Supreme Court recognized this in Obergefell. In American context, the definition of marriage is a basic issue that requires democratic processes to take place before a change therein is introduced. However, this is true only provided that said processes do not trample upon fundamental rights. Said the Obergefell Court, "Of course, the Constitution contemplates that democracy is the appropriate process for change, so long as that process does not abridge fundamental rights. ${ }^{, 39}$ This Obergefell argument for the Opinion is clear. Redefining marriage is well within the legislative authority of state legislatures in the U.S. However, the traditional definition of marriage, which excludes unions between same-sex couples, abridges a fundamental right according to Obergefell. The Court thus treated the issue of recognition of same-sex marriage as a legal question, not a political one, for there were judicially discoverable and manageable standards of Due Process and Equal Protection clauses of the U.S. Constitution, under which the right to marry is a fundamental right.

38 James R. May, AEP v. Connecticut and the Future of the Political Question Doctrine, 121 YALE L.J. ONLINE 127 (2011), http://yalelawjournal.org/2011/09/13/may.html. 
In sum, the Obergefell issues did not fall to the first 'primary category' of 'modern political questions' because while redefining marriage may be textually demonstrable to be constitutionally committed to legislative bodies through the power to legislate, yet legislation as a democratic process should not abridge fundamental rights. Likewise, the Obergefell issues did not fall to the second 'primary category' of 'modern political questions' because there was no 'lack of judicially discoverable and manageable standards.'

In Philippine jurisprudence, the case of Tañada v. Cuenco succinctly elucidated the political question doctrine as follows:

The term 'political question' connotes what it means in ordinary parlance, namely, a question of policy. It refers to 'those questions which, under the Constitution, are to be decided by the people in their sovereign capacity; or in regard to which full discretionary authority has been delegated to the legislative or executive branch of the government. It is concerned with issues dependent upon the wisdom, not legality, of a particular measure. ${ }^{40}$

In other words, a political issue has to be decided by the political branches of the government, referring to the legislative or the executive branch of government. For instance, in the Philippines, the issue of whether to give recognition to same-sex marriage is a political question. Marriage is defined in the Family Code of the Philippines. Therefore, the recognition of same-sex marriage would require an amendment of the definition of marriage. This can be done by the Congress of the Philippines by amending the statutory definition of marriage, which is a question in regard to which full discretionary legislative authority has been delegated to the Congress of the Philippines under the 1987 Constitution of the Philippines. It appears then that the issue of defining marriage is textually committed to the Congress of the Philippines.

Under the doctrine of separation of powers, legislative power has been vested in the Congress of the Philippines consisting of the Senate and the House of Representatives, ${ }^{41}$ executive power has been vested in

40 Tañada v. Cuenco, 100 Phil. 1101.

41 Section 1 of Article VI of the 1987 Constitution of the Philippines provides, "The legislative power shall be vested in the Congress of the 
the President of the Philippines, ${ }^{42}$ and judicial power and the power of judicial review have been vested in one Supreme Court and in such lower courts as maybe established by law. ${ }^{43}$ In accordance with this doctrine, the Congress of the Philippines would be deemed to have decided a political question should it pass a law amending the definition of marriage to include unions between same-sex couples. In other words, it is not within the province of Philippine courts, particularly the Supreme Court of the Philippines, to decide political questions if they wish to remain consistent to the doctrine of separation of powers. This is the prevailing norm in the Philippines. But ironically, the doctrine of separation of powers, from which the political question arose, is based on the constitutional legal framework of U.S. "The doctrine of separation of powers, derived from the American constitutional legal framework," writes Dean Candelaria of Ateneo de Manila University School of Law, "has been the foundation of Philippine constitutional structure since the Commonwealth period." 44

It is true that the expansion of the definition of marriage to include same-sex unions is not yet a worldwide phenomenon considering its rejection in the Muslim world. ${ }^{45}$ However, Obergefell cemented the acceptance of same-sex marriages in the American society. And since many states in the international community look upon the United States as worthy to emulate in certain facets of democracy, it is not an overstatement that sooner or later, the expanded definition of marriage will become the new normal while the traditional or historic definition of

Philippines which shall consist of a Senate and a House of Representatives..."

42 Section 1 of Article VII of the 1987 Constitution of the Philippines provides, "The executive power shall be vested in the President of the Philippines."

43 Section 1 of Article VIII of the 1987 Constitution of the Philippines provides, "The judicial power shall be vested in one Supreme Court and in such lower courts as may be established by law."

44 Sedfrey M. Candelaria, "The Doctrine of Separation of Powers Through the Prism of Impeachment: Context Issues and Lessons Learned," The Integrated Bar of the Philippines Journal, Special Issue No.1 (March 2012): 21.

45 See "Status of same-sex marriage," http://en.wikipedia.org, accessed August 27, 2017, 4:06 PM. 
marriage the exception. This is not a distant possibility. In fact, the eventual acceptance of same-sex marriage in America was only a matter of time as it gradually transitioned from rejection to approval by the majority of the Americans.

Posner writes, "In 1992, public opinion polls revealed that only twenty-seven percent of Americans favored allowing homosexual marriage; today a majority do, and the percentage is likely to grow as a result of the Supreme Court's decision [referring to Obergefell], the decline of religious orthodoxy, and the 'normalization' of homosexuality through marriage." 46 It has been proffered that "the political and philosophical aphorism of one generation is doubted by the next and entirely discarded by the third."

Now, same-sex marriage is legally recognised in Taiwan making the latter the first in Asia to extend recognition to this type of marriage, with its court holding that a provision in the civil code that bars same-sex marriages violated the constitutional safeguards on human dignity and equality under the law. ${ }^{47}$ In the Philippines, the incumbent Speaker of the House of Representatives (Congressman Alvarez) is already contemplating to propose a legislation that seems to afford a degree of legality to same-sex marriage. ${ }^{48}$ Hence, just like how it gradually crystallised in America, the acceptance of same-sex marriage in the whole world, save in Muslim countries probably, is just a matter of time.

\section{DUE PROCESS AND THE ISSUE OF NON-RECOGNITION OF SAME-SEX UNIONS}

According to the U.S. Supreme Court in Obergefell v. Hodges, the Fourteenth Amendment of the U.S. Constitution requires a State to

46 Richard A. Posner, "Eighteen Years On: A Re-Review," The Yale Law Journal Vol. 125 No. 2 (2015): 535, accessed August 27, 2017.

47 "Taiwan becomes 1st in Asia to recognize same-sex marriage," The Philippine Star, accessed May 25, 2017, 6:14 PM, http://www.philstar.com; "Taiwan court rules in favor of gay marriage in Asia first," ABS-CBN News, accessed May 25, 2017, 6:11 PM, http://www.news.abs-cbn.com.

48 "House Speaker wants same-sex marriage legalized," ABS-CBN News, accessed October 4, 2016, 11:36 PM, http://www.news.abs-cbn.com. 
license a marriage between two people of the same sex. Section 1 of the Fourteenth Amendment of the U.S. Constitution reads as follows:

All persons born or naturalized in the United States, and subject to the jurisdiction thereof, are citizens of the United States and of the State wherein they reside. No State shall make or enforce any law which shall abridge the privileges or immunities of citizens of the United States; nor shall any State deprive any person of life, liberty, or property, without due process of law; nor deny to any person within its jurisdiction the equal protection of the laws. ${ }^{49}$

In the Opinion of the Court, it was held that the right to marry is fundamental under Due Process Clause. ${ }^{50}$ To support its conclusion, the Court laid down four principles and traditions that "demonstrate that the reasons marriage is fundamental under the Constitution apply with equal force to same-sex couples." hereunder reproduced, namely:

A first premise of the Court's relevant precedents is that the right to personal choice regarding marriage is inherent in the concept of individual autonomy....

A second principle in this Court's jurisprudence is that the right to marry is fundamental because it supports a two-person union unlike any other in its importance to the committed individuals....

A third basis for protecting the right to marry is that it safeguards children and families and thus draws meaning from related rights of childrearing, procreation, and education....

Fourth and finally, this Court's cases and the Nation's traditions make clear that marriage is a keystone of our social order. ${ }^{52}$

49 Section 1, Amendment XIV (Ratified on July 9, 1868), The Constitution of the United States of America. [Boldfacing supplied]

50 Obergefell v. Hodges, supra, 11.

51 Ibid, 12.

52 Ibid, 12-16. Extended discussions on these principles and traditions are omitted. 


\section{DUE PROCESS UNDER THE PHILIPPINE CONSTITUTION AND THE RIGHT TO MARRY}

There is a need to determine if the right to marry is likewise fundamental under the Due Process Clause of the 1987 Constitution of the Philippines. The Due Process Clause, Philippine-perspective, is treated in Section 1 of Article III (Bill of Rights) of the 1987 Constitution of the Philippines in the following language, to wit:

No person shall be deprived of life, liberty, or property without due process of law, nor shall any person be denied the equal protection of the laws.

It is important to note that due process does not have a definite or precise meaning in Philippine jurisprudence. In Ermita-Malate Hotel \& Motel Operators Assn. v. City of Manila, ${ }^{53}$ the Supreme Court of the Philippines spoke of due process as "responsiveness to the supremacy of reason, obedience to the dictates of justice." The late Justice Isagani $\mathrm{Cruz}^{54}$ of the Supreme Court of the Philippines, speaking about due process, wrote that:

Due process is a guaranty against any arbitrariness on the part of the government, whether committed by the legislature, the executive, or the judiciary. If the law itself unreasonably deprives a person of his life or his liberty or his property, he is denied the protection of due process. If the enjoyment of his rights is conditioned on an unreasonable requirement, due process is likewise violated. Whatsoever be the source of such rights, be it the Constitution itself or merely a statute, its unjustified withholding would also be a violation of due process. Any government act that militates against the ordinary

5320 SCRA 849. (SCRA means Supreme Court Reports Annotated)

54 The late Isagani A. Cruz was a former Associate Justice of the Supreme Court of the Philippines. He was an authority in Constitutional Law in the Philippines. His book on Constitutional Law was awarded by the Supreme Court of the Philippines with the Centenary Book Award in 2000. This book continues to be a standard treatise on Constitutional Law in the Philippines. 
norms of justice or fair play is considered an infraction of the great guaranty of due process, and this is true whether the denial involves violation merely of the procedure prescribed by the law or affects the very validity of the law itself. ${ }^{55}$

Elucidating on the purpose of the constitutional safeguard of due process, the late Sen. Miriam Defensor Santiago ${ }^{56}$ of the Philippine Senate wrote, thus:

The purpose of the guaranty is to prevent governmental encroachment against the life, liberty, and property of individuals; to secure the individual from the arbitrary exercise of the powers of the government, unrestrained by the established principles of private rights and distributive justice; to protect property from confiscation by legislative enactments, from seizure, forfeiture, and destruction without a trial and conviction by the ordinary mode of judicial procedure; and to secure to all persons equal and impartial justice and the benefit of the general law. ${ }^{57}$

In nut shell, this constitutional safeguard is guaranty against deprivation of life, liberty, and property without due process of law. It is essential therefore to determine where the right to marry finds its basis in the right to life, liberty, or property. Justice Cruz wrote, "Life as understood under the due process clause connotes in the first place the integrity of the physical person." Supreme Court of the Philippines, "should not be dwarfed into mere

55 Isagani A. Cruz, Constitutional Law (Quezon City: Central Lawbook Publishing Co., Inc., 2003), 100-101.

56 The late Miriam Defensor Santiago was a Doctor of Juridical Science, University of Michigan, with Postdoctoral studies at: Oxford; Cambridge; Harvard; Academy of Public International Law, Peace Palace, The Hague, Netherlands; etc; Laureate, Magsaysay Award (Asian Nobel Prize); Senator of the Philippines; Judge of the International Criminal Court, Elected 2011 (Waived the post because of her life threatening illness); Author of many law books.

57 Miriam Defensor Santiago, Constitutional Law Annotated, Volume II (Manila: Rex Printing Company, Inc., 2015), 41.

58 Cruz, 103. 
animal existence." 59 Thus, Justice Cruz explained that the word should embrace the enjoyment by the individual of all the God-given faculties that can make his life worth living. ${ }^{60}$ He continued:

Included in the guaranty therefore would be his right to give full rein to all his natural attributes, to expand the horizons of his mind, to widen the reach of his capabilities, to enhance those moral and spiritual values that can make his life more meaningful and rewarding. The right of reproduction, for example, and the resultant savoring of the joys of parenthood, are part of the life vouchsafed to the individual under due process of law. ${ }^{61}$

It is conceded that the choice of one's partner in life regardless of his or her sex is embraced in the concept of liberty, setting aside in the meantime the legal consequences of that act in different jurisdictions around the world. Elucidating about liberty, Justice Cruz observed that:

Subject only to the reasonable restrictions of the law, a person is free to do as he pleases. He may marry for love or for money, pursue a profession or engage in manual labor, establish his own business or merely hire out as an employee, isolate himself from the community or mix with his neighbors, profess a religion or embrace atheism - in short, do anything that does not offend the public welfare. ${ }^{62}$

There is no jurisprudence yet in the Philippines whose doctrine is the fundamental character of the right to marry under the Due Process Clause of the 1987 Constitution of the Philippines. This notwithstanding, the present writer concedes that indeed the right to marry is likewise fundamental in the Due Process Clause of the 1987 Constitution of the Philippines. A perusal of the pertinent provisions of said Constitution reveals a constitutional recognition of the right to marry. This is evident in the provisions of Section 12 of Article II and Sections 1 to 3 of Article

\footnotetext{
59 Rubi v. Provincial Board of Mindoro, 39 Phil. 660.

60 Cruz, 104.

61 Ibid.

62 Cruz, 105.
} 
XV of the 1987 Constitution of the Philippines. ${ }^{63}$ The fact that a separate article in the Constitution is devoted to the family simply means that marriage, to which the right to marry is subsumed, is at the centrality of the State's effort to strengthen the solidarity of the Filipino family and to actively promote its total development.

However, while it is conceded that the right to marry is fundamental under the Due Process Clause of the 1987 Constitution of the Philippines, such a concession does not necessarily include a proposition that the right to marry in the Philippines includes compulsory state recognition of same-sex unions. At present, same-sex unions in the Philippines do not enjoy the imprimatur of the State that is necessary to equalize them with opposite-sex marriages. Obergefell $v$. Hodges is not binding upon the Supreme Court of the Philippines. It can be given a persuasive weight at best, or it can be entirely disregarded at worst.

However, as pointed out earlier in this paper, the 1987 Constitution of the Philippines failed to define marriage in a language that includes the 'union between a man and a woman' element. This implies that the Philippine Constitution does not straitjacket the Supreme Court of the Philippines insofar as the exact definition of marriage is concerned. However, there is likewise no constitutional impediment for the Supreme Court of the Philippines to adhere to the traditional or historic definition

63 Section 12 of Article II of the 1987 Constitution of the Philippines provides, "The State recognizes the sanctity of family life and shall protect and strengthen the family as a basic autonomous social institution. It shall equally protect the life of the mother and the life of the unborn from conception. The natural and primary right and duty of parents in the rearing of the youth for civic efficiency and the development of moral character shall receive the support of the Government."

Article XV, Section 1. The State recognizes the Filipino family as the foundation of the nation. Accordingly, it shall strengthen its solidarity and actively promote its total development. Section 2. Marriage, as an inviolable social institution, is the foundation of the family and shall be protected by the State. Section 3. The State shall defend:

(1) The right of spouses to found a family in accordance with their religious convictions and the demands of responsible parenthood;

(2) $\mathrm{xxx} \quad \mathrm{xxx}$

(3) The right of the family to a family living wage and income; and

(4) The right of families or family associations to participate in the planning and implementation of policies and programs that affect them. 
of marriage by acknowledging the natural-law context of the constitutional provisions on family and marriage. It is a familiar learning in constitutional law that the Constitution is what the Supreme Court says it is.

Pursuant to existing laws in the Philippines, Local Civil Registrars may validly refuse the registration of same-sex marriages, invoking the Family Code of the Philippines which limits marriage to the union between a man and a woman. However, if such a case - involving the issue of constitutionality of non-recognition of same-sex marriage - is elevated to the Supreme Court of the Philippines on pure question of law, said Court may hold that the definition of marriage in the Family Code of the Philippines is unconstitutional invoking Obergefell vs. Hodges.

This is but an exercise of judicial power and the power of judicial review granted by the Constitution to the Supreme Court of the Philippines. Judicial power includes the duty of the courts of justice to settle actual controversies involving rights which are legally demandable and enforceable, and to determine whether or not there has been a grave abuse of discretion amounting to lack or excess of jurisdiction on the part of any branch or instrumentality of the Government. ${ }^{64}$ In the exercise of the power of judicial review, the Supreme Court of the Philippines may decree that in excluding same-sex unions from the definition of marriage thereby resulting to the denial of benefits by reason of the exclusion, the provision of the Family Code of the Philippines that defines marriage violates the right to due process of same-sex couples.

In Ang Ladlad LGBT Party v. Commission on Elections, ${ }^{65}$ the Commission on Elections disqualified the petitioner, which is a group of lesbians, gays, bisexuals, and transgendered individuals, from participating in the party-list elections because of its belief in same-sex union which, according to the Commission on Elections, is not sanctioned by the Holy Qur'an or the Bible. Reversing the assailed resolutions of the Commission on Elections, the Supreme Court of the Philippines ruled that the belief of Ang Ladlad LGBT Party in same-sex marriage is not a valid ground to disqualify it from participating in the party-list elections. In denying accreditation to Ang Ladlad LGBT Party using religious standards, the Commission on Elections, according to the

\footnotetext{
64 Section 1, Article VIII, 1987 Constitution of the Philippines.

65

G.R. No. 190582, April 8, 2010.
} 
Supreme Court of the Philippines, violated the Non-Establishment Clause $^{66}$ of the Philippine Constitution. Said the Supreme Court in Ang Ladlad LGBT Party v. Commission on Elections: ${ }^{67}$

Our Constitution provides in Article III, Section 5 that "[n]o law shall be made respecting an establishment of religion, or prohibiting the free exercise thereof." At bottom, what our non-establishment clause calls for is "government neutrality in religious matters." Clearly, "governmental reliance on religious justification is inconsistent with this policy of neutrality." We thus find that it was grave violation of the non-establishment clause for the COMELEC to utilize the Bible and the Koran to justify the exclusion of Ang Ladlad.

\section{EQUAL PROTECTION AND THE ISSUE OF NON- RECOGNITION OF SAME-SEX UNIONS}

Obergefell further held that the right of same-sex couples to marry that is part of the liberty promised by the Fourteenth Amendment is derived, too, from that Amendment's guarantee of the equal protection of the laws. ${ }^{68}$ Said the U.S. Supreme Court in the same case:

Here the marriage laws enforced by the respondents are in essence unequal: same-sex couples are denied all the benefits afforded to opposite-sex couples and are barred from exercising a fundamental right. Especially against a long history of disapproval of their relationships, this denial to same-sex couples of the right to marry works a grave and continuing harm. The imposition on this disability on gays and lesbians serves to disrespect and subordinate them. And the Equal Protection Clause, like the Due Process Clause, prohibits this unjustified infringement of the fundamental right to marry. ${ }^{69}$

No union is more profound than marriage, for it embodies the highest ideals of love, fidelity, devotion, sacrifice, and family. In forming a marital union, two

66 Section 5, Article III, 1987 Constitution of the Philippines: "No law shall be made respecting an establishment of religion, ...".

67 Ang Ladlad LGBT Party v. Commission on Elections. [Citations omitted]

68 Obergefell v. Hodges, 19.

69 Ibid. at 22. 
people become something greater than once they were. As some of the petitioners in these cases demonstrate, marriage embodies a love that may endure even past death. It would misunderstand these men and women to say they disrespect the idea of marriage. Their plea is that they do respect it, respect it so deeply that they seek to find its fulfillment for themselves. Their hope is not to be condemned to live in loneliness, excluded from one of civilization's oldest institutions. They ask for equal dignity in the eyes of the law. The Constitution grants them that right. ${ }^{70}$

Section 1 of Article III (Bill of Rights) of the 1987 Constitution of the Philippines articulates the Equal Protection Clause as follows: "Nor shall any person be denied the equal protection of the laws." The Supreme Court of the Philippines had the occasion to elucidate on the concept of the Equal Protection Clause in Biraogo v. Philippine Truth Commission of $2010{ }^{71}$ as follows:

One of the basic principles on which this government was founded is that of the equality of right which is embodied in Section 1, Article III of the 1987 Constitution. The equal protection of the laws is embraced in the concept of due process, as every unfair discrimination offends the requirements of justice and fair play. It has been embodied in a separate clause, however, to provide for a more specific guaranty against any form of undue favoritism or hostility from the government. Arbitrariness in general may be challenged on the basis of the due process clause. But if the particular act assailed partakes of an unwarranted partiality or prejudice, the sharper weapon to cut it down is the equal protection clause.

According to a long line of decisions, equal protection simply requires that all persons or things similarly situated should be treated alike, both as to rights conferred and responsibilities imposed. It requires public bodies and institutions to treat similarly situated individuals in a similar manner. The purpose of the equal protection clause is to secure every person within a state's jurisdiction against intentional and

\footnotetext{
70 Ibid. at 28 .

71 G.R. No. 192935, December 7, 2010.
} 
arbitrary discrimination, whether occasioned by the express terms of a statute or by its improper execution through the state's duly constituted authorities. In other words, the concept of equal justice under the law requires the state to govern impartially, and it may not draw distinctions between individuals solely on differences that are irrelevant to a legitimate governmental objective.

The equal protection clause is aimed at all official state actions, not just those of the legislature. Its inhibitions cover all the departments of the government including the political and executive departments, and extend to all actions of a state denying equal protection of the laws, through whatever agency or whatever guise is taken.

It, however, does not require the universal application of the laws to all persons or things without distinction. What it simply requires is equality among equals as determined according to a valid classification. Indeed, the equal protection clause permits classification. Such classification, however, to be valid must pass the test of reasonableness. The test has four requisites: (1) The classification rests on substantial distinctions; (2) It is germane to the purpose of the law; (3) It is not limited to the existing conditions only; and (4) It applies equally to all members of the same class. "Superficial differences do not make for a valid classification."

Against this backdrop, let us take a closer look at the finding of Obergefell v. Hodges that there was a violation of the Equal Protection Clause when states in U.S. did not recognise same-sex unions thereby failing to give treatment similar to that afforded to opposite-sex marriages. To begin with, central to the concept of equal protection is the principle that even among equals, there can be a valid inequality. The only condition is that the selective treatment by the government must be based on valid classification. Classification has been defined as the grouping of persons or things similar to each other in certain particulars and different from all others in these same particulars. ${ }^{72}$

It is undeniable that there are substantial distinctions between samesex unions and opposite-sex marriages that make for real differences. One of such substantial distinctions is captured by Chief Justice Roberts in his dissenting opinion in Obergefell v. Hodges. He explained:

72 Cruz, 127, citing International Harvester Co. v. Missouri, 234 U.S. 199. 
Marriage did not come about as a result of political movement, discovery, disease, war, religious doctrine, or any other moving force of world history - and certainly not as a result of a prehistoric decision to exclude gays and lesbians. It arose in the nature of things to meet a vital need: ensuring that children are conceived by a mother and father committed to raising them in the stable conditions of a lifelong relationship. ${ }^{73}$

The premises supporting this concept of marriage are so fundamental that they rarely require articulation. The human race must procreate to survive. Procreation occurs through sexual relations between a man and a woman. When sexual relations result in the conception of a child, that child's prospects are generally better if the mother and father stay together rather than going their separate ways. Therefore, for the good of children and society, sexual relations that can lead to procreation should occur only between a man and a woman committed to a lasting bond. ${ }^{74}$

The Congress of the Philippines enacted Republic Act No. 10354, otherwise known as the Responsible Parenthood and Reproductive Health Act of 2012, with clear reference to opposite-sex unions because it is only in which reproduction, as a matter of nature, could possibly occur. In the Philippines, working mothers are entitled to maternity leave and other benefits. In grocery stores and similar business establishments, there are designated priority lanes for pregnant women. In airports in the Philippines, there are breastfeeding sections for nursing mothers. There are reception areas in government offices that are intended for pregnant women who are transacting therein. All these benefits are limited to women for the simple reason that a man is not a woman who is susceptible to pregnancy. This substantial distinction makes for a real difference between a man and a woman. Hence, the rights and benefits given by the State to women by reason of their biological peculiarities as females can be validly denied to men. Likewise, rights and benefits given by the State to opposite-sex marriages by reason of possibility of procreation, reproduction, rearing of children 'produced,' etc., can be

\footnotetext{
73 Obergefell v. Hodges, Roberts, C.J., dissenting, 4-5.

74 Ibid, 5.
} 
validly denied to same-sex unions where there is zero possibility of procreation.

Such a state favoritism tilted towards women vis-à-vis men and opposite-sex marriages vis-à-vis same-sex unions is based on a valid classification. The Holy Qur'an tells us that it was never 'Adam' and 'Steve' or 'Genevieve' and 'Eve.' The original normal was Adam, a man, and Eve, a woman. The state therefore can be selective in its treatment of same-sex unions and opposite-sex marriages if the selective treatment arises from a valid classification at the centrality of which is the possibility of procreation in opposite-sex marriages while there is zero possibility in same-sex unions. For this, the state cannot be said to have become irrational and bias. The state is simply responding to reason and natural truth that needs no exhaustive articulation and debate. As succinctly said by Chief Justice Roberts:

In any event, the marriage laws at issue here do not violate the Equal Protection Clause, because distinguishing between opposite-sex and same-sex couples is rationally related to the State's "legitimate state interest" in "preserving the traditional institution of marriage." 75

Indeed and rightfully so, statutory laws in the Philippines dictate that the nature, consequences, and incidents of marriage are governed by law and not subject to stipulation. The law, in governing the nature, consequences, and incidents of marriage, should not operate at the mercy of individual preferences and choices that contradict the very nature of marriage as a union between a man and a woman. If this is not so, then proponents of union between a person and a mannequin or a Teddy bear or a digital woman or man, or a pet, may likewise ask the State to extend recognition to such a union if the dominating notion is that individual preferences and choices, which contradict the very nature of marriage as union between a man and a woman, are above the law. The preservation of the traditional institution of marriage is a legitimate state interest that the state has the right to protect.

\section{CONCLUSION}

Ibid, 24. 
The Obergefell decision forces a dichotomy in the definition of marriage. One is adherent to the traditional or historic definition of marriage, while the other expands its scope to include same-sex unions invoking the constitutional right to marry which is fundamental in the Due Process Clause and the Equal Protection Clause of democratic constitutions like the 1987 Constitution of the Philippines. Same-sex marriage has in the past been the subject of a political debate the resolution of which should have ideally culminated in the hands of legislators. However, the U.S. Supreme Court ended that political debate in the United States by holding, in effect, that the definition of marriage, which excludes in its scope the union of persons of the same sex, offends the Due Process Clause and the Equal Protection Clause of the U.S. Constitution. Though the U.S. Supreme Court is often looked upon in the Philippines for its instructive and landmark decisions, ${ }^{76}$ however, the doctrine in Obergefell may find it difficult to blossom in the legal system of the Philippines. This is true especially in the regime of Muslim Personal Laws embodied in the Code of Muslim Personal Laws of the Philippines whose definition of marriage is anchored on the Holy Qur'an and Sunnah which are the primary sources of Muslim law and cannot be abrogated by man-made legislation.

Had the concept of same-sex marriage been the pressing issue in the Philippines, conclusions would have been reached to the effect that the issue of whether the State should legally recognize same-sex marriage is a political question and not a justiciable one. As a political question, the Supreme Court of the Philippines cannot decide on it in view of the doctrine of separation of powers from which arose the political question doctrine. As earlier posited, the resolution of political issues should be best left to the political branches of government, referring to the legislative or executive branch of government. However, considering that the definition of marriage in the 1987 Constitution of the Philippines lacks the 'union between a man and a woman' language, there is,

76 In fact, many doctrinal cases decided by the U.S. Supreme Court pervade in Philippine jurisprudence. Some of these cases include inter alia the following: Griswold v. Connecticut, 381 U.S. 479; Yick Wo v. Hopkins, 118 U.S. 356; Brown v. Board of Education of Topeka, 349 U.S. 294; Engel v. Vitale, 370 U.S. 421; Miranda v. Arizona,384 U.S. 436; Miller v. California, 37 L. ed. 2nd 419;Terry v. Ohio, 392 U.S. 1; United States v. O'Brien, 391 U.S. 367. 
possibly, no constitutional impediment for the Supreme Court of the Philippines to imitate the U.S. Supreme Court and hold in a proper case that the non-recognition of same-sex unions in the Philippines offends the Due Process Clause and the Equal Protection Clause of the Philippine Constitution.

Be it a judicial pronouncement or through a legislative fiat, any modified definition of marriage that includes same-sex unions will be inconsistent with the Islamic definition of marriage. This calls for a legal accommodation for Muslims in the Philippines by making such a modified definition of marriage inapplicable to Muslim marriages under the Code of Muslim Personal Laws of the Philippines. Should a modified definition of marriage come by way of judicial pronouncement of the Supreme Court of the Philippines, then I cannot suppress the temptation to respond thereto by pointing to the concluding part of the dissent of Chief Justice Roberts. He said:

If you are among the many Americans - of whatever sexual orientation - who favor expanding same-sex marriage, by all means celebrate today's decision. Celebrate the achievement of a desired goal. Celebrate the opportunity for a new expression of commitment to a partner. Celebrate the availability of new benefits. But do not celebrate the Constitution. It had nothing to do with it. ${ }^{77}$ 